Wahana Didaktika Vol. 16 No.3 September 2018 : 376-386

\title{
EVALUASI RENCANA PELAKSANAAN PEMBELAJARAN KURIKULUM 2013 GURU MADRASAH IBTIDAIYAH
}

\author{
Oleh: Miftha Indasari ${ }^{1}$, Linda Lia $^{2}$, Asnurul Isroqmi ${ }^{3}$ \\ (Dosen Universitas PGRI Palembang ${ }^{123}$ ) \\ Email :mithaindasari21@gmail.com ${ }^{1}, \underline{\text { lindalia_burhan@yahoo.com }}{ }^{2}$, \\ asnurul@gmail.com ${ }^{3}$
}

\begin{abstract}
Abstrak
Tujuan penelitian ini adalah untuk: (1) mengetahui sikap guru dalam pembuatan RPP kurikulum 2013; (2) mengevaluasi RPP kurikulum 2013 yang dibuat guru. Penelitian ini merupakan penelitian kualitatif dengan metode deskriptif. Metode pengumpulan data menggunakan lembar penilaian RPP, angket, wawancara, dan dokumentasi. Subjek penelitian yaitu RPP yang dibuat oleh 37 orang guru MI di Kecamatan Indralaya. Berdasarkan hasil angket diperoleh persentase sikap guru dalam membuat RPP kurikulum 2013 sebesar 35\% dengan kategori baik. Berdasarkan lembar penilaian RPP diperoleh: (1) skor rata-rata sebesar 3,16 dengan kategori baik untuk aspek penyusunan RPP; (2) skor rata-rata sebesar 2,72 dengan kategori baik untuk aspek prinsip penyusunan RPP; (3) skor rata-rata sebesar 3,22 dengan kategori baik untuk aspek komponen dan sistematika RPP; dan (4) skor rata-rata sebesar 3,00 dengan kategori baik untuk aspek langkah-langkah penyusunan RPP. Dengan demikian dapat disimpulkan bahwa RPP kurikulum 2013 disusun dengan baik oleh guru dan setelah diperbaiki dapat diimplementasikan dalam pembelajaran.
\end{abstract}

Kata Kunci: Evaluasi, Rencana Pelaksanaan Pembelajaran, Kurikulum 2013

\section{EVALUATION OF LESSON PLAN IN THE CURICCULUM 2013 FOR MADRASAH IBTIDAIYAH TEACHERS}

\begin{abstract}
The objectives of this study are: (1) to find out the attitudes of teachers in making lesson plan in the curriculum 2013; (2) to evaluate lesson plan made by teachers. This study used qualitative research with descriptive method. The data were collected using the assessment instrument, questionnaire, interview, and documentation. The subjectconsist of 37 lesson plan. The results of the questionnaire obtained the percentage of teacher attitudes are $35 \%$ (good category). The results of the assessment instrument show that: (1) average score of 3.16 with good category (lesson plan preparation); (2) average score of 2.72 with good category (lesson plan preparation principle); (3) average score of 3.22 with good category (lesson plan component and systematic); (4) average score of 3.00 with good category (lesson plan preparation steps). Lesson plan in the curriculum 2013 is well prepared by teachers and after it is improved it can be implemented.
\end{abstract}


Evaluasi Rencana Pelaksanaan....(Miftha Indasari, Linda Lia dan Asnurul Isroqmi)

Keywords: Evaluation, Lesson Plan, Curicculum 2013

\section{A. PENDAHULUAN}

Kurikulum berperan penting dalam menentukan kualitas pendidikan. Menurut PP nomor 32 tahun 2013 tentang perubahan standar nasional pendidikan bahwa kurikulum adalah seperangkat rencana dan pengaturan mengenai tujuan, isi, dan bahan pelajaran serta cara yang digunakan sebagai pedoman penyelenggaraan kegiatan pembelajaran untuk mencapai tujuan pendidikan tertentu.

Kurikulum pendidikan di Indonesia telah beberapa kali mengalami perkembangan. Hidayat (2013) menjelaskan bahwa beberapa perkembangan kurikulum tersebut yaitu rencana pelajaran 1947, rencana pelajaran terurai 1952, rencana pendidikan 1964, kurikulum 1968, kurikulum 1975, kurikulum 1984, kurikulum 1994, kurikulum berbasis kompetensi 2004, kurikulum tingkat satuan pendidikan pada tahun 2006. Kurikulum KTSP tahun 2006 mengalami perkembangan menjadi kurikulum 2013. Kurikulum 2013 secara bertahap mulai diberlakukan pada tahun ajaran 2013/2014. Penerapan kurikulum 2013 di beberapa sekolah juga diperkuat dengan adanya surat edaran Mendikbud nomor 156928/MPK.A/KR/2013 tanggal 08 November 2013 tentang implementasi kurikulum 2013 dan disusul oleh surat edaran bersama Menteri Dalam Negeri RI dan Menteri Pendidikan dan Kebudayaan RI nomor: 420/176/SJ dan Nomor: 0258/MPK.A/KR/2014 tentang implementasi kurikulum 2013. Kurikulum 2013 dianggap sesuai dengan perkembangan zaman dan kebutuhan masyarakat.

Kurikulum 2013 yang saat ini telah menjadi kurikulum nasional di Indonesia harus mampu mewujudkan tujuan pendidikan nasional. Tujuan pendidikan nasional ditegaskan pada Pasal 3 Undang-Undang Nomor 20 Tahun 2003 tentang Sistem Pendidikan Nasional bahwa pendidikan nasional berfungsi mengembangkan kemampuan dan membentuk watak serta peradaban bangsa yang bermartabat dalam rangka mencerdaskan kehidupan bangsa, bertujuan untuk mengembangkan potensi peserta didik agar menjadi manusia yang beriman dan bertakwa kepada Tuhan Yang Maha Esa, berakhlak mulia, sehat, berilmu, cakap, kreatif, mandiri, dan menjadi warga negara yang demokratis serta bertanggung jawab. 
Menurut Wibawa \& Kartowagiran (2014) bahwa keunggulan kurikulum 2013 yaitu: (1) menekankan aspek kognitif, afektif, dan psikomotorik secara proporsional, (2) materi pembelajaran merupakan materi esensial dan relevan dengan kompetensi yang dibutuhkan, (3) menekankan pada pendidikan karakter, (4) menghasilkan lulusan yang memiliki keterampilan sesuai kebutuhan masyarakat, (5) berpusat pada peserta didik dan proses pembelajarannya kontekstual, dan (6) mengkombinasikan penilaian proses dan penilaian hasil pembelajaran.

Pengembangan kurikulum 2013 bertujuan untuk mendorong peserta didik atau siswa, mampu lebih baik dalam melakukan observasi, bertanya, bernalar, dan mengkomunikasikan, apa yang mereka peroleh atau mereka ketahui setelah menerima materi pembelajaran yang menggunakan pendekatan ilmiah dalam proses pembelajaran (Wibawa \& Kartowagiran, 2014). Dalam Permendikbud No. 22 tahun 2016 tentang Standar Proses Pendidikan Dasar dan Menengah disebutkan bahwa salah satu prinsip pembelajaran yang penting dalam Kurikulum 2013 adalah dari pendekatan tekstual menuju proses sebagai penguatan penggunaan pendekatan ilmiah. Pendekatan ilmiah adalah proses pembelajaran yang dirancang sedemikian rupa agar peserta didik secara aktif menkonstruksi konsep, hukum atau prinsip melalui tahapan-tahapan mengamati (untuk mengidentifikasi atau menemukan masalah), merumuskan masalah, mengajukan atau merumuskan hipotesis, mengumpulkan data dengan berbagai teknik, menganalisis data, menarik kesimpulan dan mengomunikasikan konsep, hukum atau prinsip yang ditemukan (Machin, 2014).

Permendikbud Nomor 67 Tahun 2013 tentang Kerangka Dasar dan Struktur Kurikulum SD/MI menyatakan bahwa Pelaksanaan Kurikulum 2013 pada SD/MI dilakukan melalui pembelajaran tematik terpadu dari Kelas I sampai Kelas VI. Pembelajaran tematik terpadu menekankan pada pengintegrasian semua mata pelajaran dengan pengalaman belajar yang berbasis pada pengalaman peserta didik dan struktur dunia nyata, sehingga mendorong pembelajaran menjadi lebih bermakna (Erviana, 2016). Pembelajaran tematik adalah pembelajaran yang melibatkan beberapa mata pelajaran atau pembelajaran terpadu melalui tema 
Evaluasi Rencana Pelaksanaan....(Miftha Indasari, Linda Lia dan Asnurul Isroqmi)

(Pitadjeng, 2009). Pelaksanaan kurikulum 2013 SD/MI menggunakan pembelajaran tematik terpadu dengan pendekatan ilmiah.

Implementasi kurikulum 2013 telah dilaksanakan hampir di setiap SD/MI di Indonesia. Dalam rangka pencapaian tujuan dari implementasi tersebut maka Permendikbud No. 22 tahun 2016 tentang Standar Proses Pendidikan Dasar dan Menengah Bab III mengatur tentang perencanaan pembelajaran bahwa perencanaan pembelajaran dirancang dalam bentuk Silabus dan Rencana Pelaksanaan Pembelajaran (RPP) yang mengacu pada Standar Isi. Oleh karena itu, guru diharuskan membuat perencanaan pembelajaran sebagaimana dimaksud dan kesiapan guru dalam membuat perencanaan pembelajaran harus dievaluasi.

Proses pembelajaran pada satuan pendidikan diselenggarakan secara interaktif, inspiratif, menyenangkan, menantang, memotivasi peserta didik untuk berpartisipasi aktif, serta memberikan ruang yang cukup bagi prakarsa, kreativitas, dan kemandirian sesuai dengan bakat, minat, dan perkembangan fisik serta psikologis peserta didik (Kemdikbud, 2015). Oleh sebab itu, guru perlu melakukan perencanaan pembelajaran yang dirancang dalam bentuk RPP untuk kelas yang menjadi tanggung jawabnya mengajar.

Permendikbud No. 22 tahun 2016 tentang Standar Proses Pendidikan Dasar dan Menengah juga menyebutkan bahwa RPP adalah rencana kegiatan pembelajaran tatap muka untuk satu pertemuan atau lebih yang dikembangkan dari silabus untuk mengarahkan kegiatan pembelajaran peserta didik dalam upaya mencapai Kompetensi Dasar (KD).Pengembangan RPP dapat dilakukan secara mandiri atau perkelompok dan disupervisi oleh kepala sekolah/madrasah.

Pengembangan RPP selayaknya dilaksanakan pada awal semester atau awal tahun pelajaran dan dievauasi setelahnya. Selanjutnya, RPP tersebut diperbaharui kembali. Bagi guru sangat penting untuk mendesain pembelajaran di kelas yang dapat memungkinkan peserta didik agar lebih aktif dan kreatif guna meningkatkan kualitas peserta didik tersebut (Erviana, 2016).

Perencanaan pembelajaran dalam penelitian ini secara spesifik yaitu RPP yang disusun mengacu pada kurikulum 2013 di MI Kecamatan Indralaya. Berdasarkan hasil wawancara dengan kepala MI Al Ittifaqiah dan MI PIAT 
Kecamatan Indralaya bahwa sekolah masih melaksanakan KTSP dalam pembelajarannya. Pada tahun ajaran berikutnya direncanakan akan menerapkan kurikulum 2013 dalam pembelajaran. Guru-guru pada kedua sekolah tersebut sudah pernah mendapatkan pelatihan kurikulum 2013 dan sudah mendapatkan pelatihan penyusunan RPP kurikulum 2013. Dalam rangka menyiapkan implementasi kurikulum 2013 pada sekolah tersebut maka diperlukan evaluasi terhadap RPP kurikulum 2013 yang telah dibuat oleh guru.

Berdasarkan latar belakang tersebut, penelitian ini bertujuan untuk mengevaluasi RPP kurikulum 2013 yang dikembangkan oleh guru MI Al Ittifaqiah dan MI PIAT Kecamatan Indralaya. Selain itu, penelitian ini juga bertujuan untuk mengetahui sikap guru dalam membuat RPP kurikulum 2013.

\section{B. METODOLOGI PENELITIAN}

Jenis penelitian ini merupakan penelitian kualitatif adalah metode penelitian yang digunakan untuk meneliti pada kondisi objek yang alamiah (Sugiyono, 2011). Hasil penelitian akan dianalisis dan dideskripsikan serta menekankan pada makna dari pada generalisasi. Subjek penelitian adalah RPP kurikulum 2013 yang telah dibuat oleh 37 orang guru terdiri dari 24 orang guru MI Al Ittifaqiah dan 13 orang guru MI PIAT di Kecamatan Indralaya. Penelitian ini dilakukan pada awal tahun ajaran 2017/2018. Ada beberapa intrumen pengumpul data yang digunakan. Instrumen tersebut yaitu lembar penilaian RPP, lembar angket, wawancara, dan dokumentasi. Lembar penilaian RRP merupakan hasil modifikasi dari Kemdikbud (2015).

\section{HASIL PENELITIAN DAN PEMBAHASAN}

Penelitian ini didahului dengan survei pendahuluan di MI Al Ittifaqiah dan MI PIAT. Survei pendahuluan dilakukan dengan cara wawancara dengan kepala madrasah. Dari hasil wawancara diperoleh data tentang jumlah guru dan keadaan guru.Guru-guru pada kedua sekolah sudah pernah mendapatkan pelatihan kurikulum 2013. Kedua sekolah juga pernah menerapkan kurikulum 2013 sebelumnya akan tetapi kedua sekolah kembali menerapkan KTSP. Selanjutnya, 
pada tahun ajaran berikutnya berdasarkan peraturan, kedua sekolah akan menerapkan kurikulum 2013.

Peneliti menyebarkan angket kepada 37 orang guru yang digunakan untuk mengukur sikap guru dalam membuat RPP kurikulum 2013. Kemudian, berdasarkan hasil angket tersebut diperoleh data persentase sikap guru dalam membuat RPP kurikulum 2013 seperti pada gambar 1 berikut.

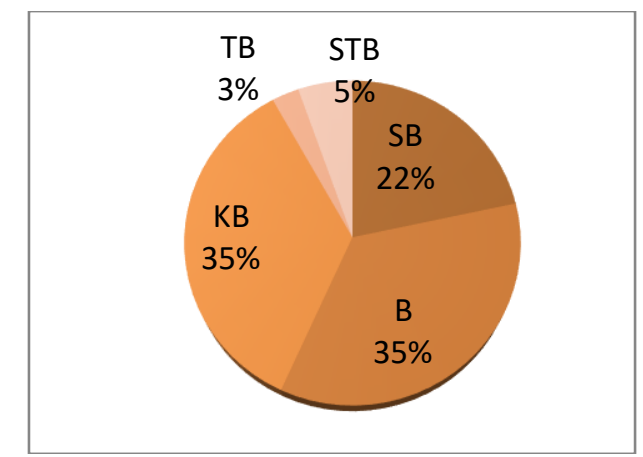

\section{Gambar 1. Persentase Sikap Guru dalam Membuat RPP}

Berdasarkan gambar di atas, dapat diketahui bahwa sikap guru dalam membuat RPP sebesar 22\% dengan kategori sangat baik (SB), 35\% dengan kategori baik (B), 35\% dengan kategori kurang baik (KB), 3\% dengan kategori tidak baik (TB), dan 5\% dengan kategori sangat tidak baik (STB). Walaupun 35\% sikap guru kurang baik dalam membuat RPP, dari data tersebut dapat simpulkan bahwa sikap guru dalam membuat RPP termasuk dalam kategori baik. Artinya guru pada kedua sekolah menyambut baik pelaksanaan kurikulum 2013 di sekolah masing-masing.

Dokumen terkait dengan RPP yang telah dibuat oleh 37 orang guru MI dari kedua sekolah dikumpulkan dan dievaluasi. Berikut persentase guru yang mampu membuat RPP.

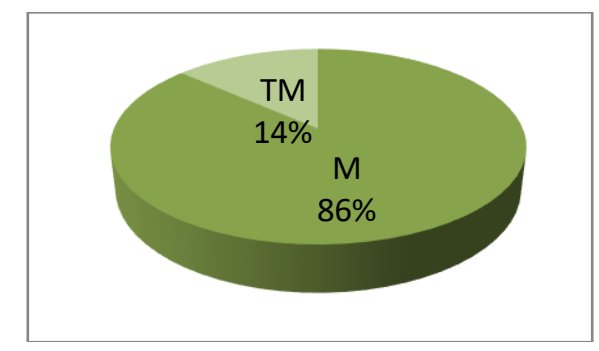

Gambar 2. Persentase Guru yang Mampu Membuat RPP 
Berdasarkan gambar 2 dapat dilihat bahwa $86 \%$ guru mampu membuat RPP (M) sedangkan 14\% guru tidak mampu membuat RPP (TM). Hasil tersebut dapat diartikan bahwa dari 37 orang yang membuat RPP hanya 32 orang yang mampu membuat RPP sedangkan 5 orang lainnya tidak mampu membuat RPP.

Instrumen yang digunakan untuk mengevaluasi RPP kurikulum 2013 merupakan hasil modifikasi dari Kemdikbud (2015). Dalam Kemdikbud (2015) menegaskan indikator penilaian RPP ditentukan berdasarkan aspek-aspek berikut: (1) Aspek penyusunan RPP; (2) aspek prinsip penyusunan RPP; (3) aspek komponen dan sistematika RPP; dan (4) aspek langkah-langkah penyusunan RPP.

Indikator pertama menunjukkan bahwa setiap guru sudah mengkaji silabus sebelum membuat RPP termasuk pada kategori sangat baik dengan skor 4,00. Indikator kedua, guru merumuskan indikator pencapaian $\mathrm{KD}$ (KI-1, KI-2, KI-3, dan KI-4) termasuk pada kategori sangat baik dengan skor 3,50. Indikator ketiga, RPP memuat materi pembelajaran berasal dari berbagai sumber belajar termasuk pada kategori baik dengan skor 2,59. Indikator keempat, RPP memuat kegiatan pembelajaran sesuai dengan kondisi peserta didik dan satuan pendidikan termasuk pada kategori baik dengan skor 2,63. Indikator kelima, alokasi waktu pertemuan berdasarkan alokasi waktu pada silabus termasuk kategori sangat baik dengan skor 3,56. Indikator keenam, RPP memuat penilaian pembelajaran termasuk kategori tidak baik denga skor 2,41. Indikator ketujuh, RPP memuat rencana strategi pembelajaran remedial dan pengayaan termasuk pada kategori tidak baik dengan skor 2,34 .

Hasil evaluasi RPP pada aspek langkah-langkah penyusunan RPP untuk indikator pertama memperoleh skor yang terbesar dengan skor 4 termasuk kategori sangat baik artinya setiap guru sudah mengkaji silabus sebelum membuat RPP. Akan tetapi, pada indikator ketujuh memperoleh skor terkecil dengan skor sebesar 2,34 termasuk kategori tidak baik. Jumlah guru yang membuat RPP sebanyak 32 orang artinya hanya sebanyak $34 \%$ guru menyusun RPP memuat rencana strategi pembelajaran remedial dan pengayaan dengan baik.

Evaluasi RPP dilakukan berdasarkan empat aspek yaitu aspek penyusunan RPP, aspek prinsip penyusunan RPP, aspek komponen \& sistematika RPP, dan 
aspek langkah-langkah penyusunan RPP. Berdasarkan data hasil penelitian yang diperoleh dapat dilakukan perbandingan skor rata-rata keempat aspek tersebut. Berikut data perbandingan skor rata-rata hasil evaluasi pada keempat aspek seperti terlihat pada gambar 3 .

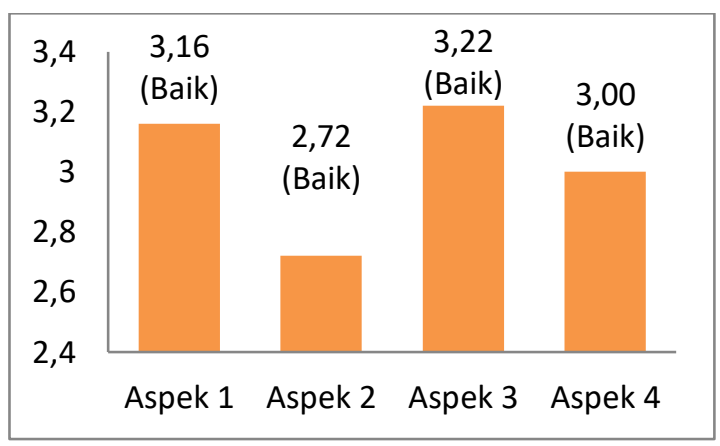

\section{Gambar 3. Perbandingan Skor Rata-rata Hasil Evaluasi RPP}

Berdasarkan gambar 3 di atas, dapat dilihat perbandingan skor rata-rata hasil evaluasi RPP berdasarkan indikator penilaian keempat aspek RPP. Aspek pertama, aspek penyusunan RPP memperoleh skor rata-rata sebesar 3,16 dengan kategori baik. Aspek kedua, aspek prinsip penyusunan RPP memperoleh skor rata-rata sebesar 2,72 dengan kategori baik. Aspek ketiga, aspek komponen dan sistematika RPP memperoleh skor sebesar 3,22 dengan kategori baik. Terakhir aspek keempat, aspek langkah-langkah penyusunan RPP memperoleh skor ratarata sebesar 3,00 dengan kategori baik.

Skor rata-rata terbesar diperoleh pada aspek ketiga yaitu aspek komponen dan sistematika RPP dengan skor 3,22 kategori baik. Akan tetapi skor rata-rata terendah diperoleh pada aspek kedua yaitu aspek prinsip penyusunan RPP dengan skor 2,72 kategori baik. Oleh karena itu, dalam menyusun RPP hendaknya guru memperhatikan prinsip-prinsip penyusunan RPP sebagaimana yang diamanatkan pada Permendikbud No. 22 tahun 2016 tentang Standar Proses Pendidikan Dasar dan Menengah Bab III mengatur tentang perencanaan pembelajaran.

Secara umum, RPP kurikulum 2013 yang disusun oleh guru Madrasah Ibtidaiyah sudah baik dan bisa diimplementasikan. Namun, ada beberapa kelemahan atau koreksi berdasarkan hasil evaluasi keempat aspek RPP yang perlu diperbaiki dalam RPP tersebut yaitu: (1) RPP yang disusun sebaiknya 
memperhatikan lingkungan sekitarnya sebagai sumber belajar; (2) RPP hendaknya memuat penilaian dengan baik; (3) RPP hendaknya memuat rencana strategi pembelajaran remedial dan pengayaan. Ketiga hal inilah yang harus diperbaiki lagi oleh guru dalam membuat RPP kurikulum 2013.

Menurut Wibawa \& Kartowagiran (2014) menjelaskan bahwa perangkat pembelajaran dalam hal ini RPP memiliki peran yang sangat penting dalam mengimplementasikan kurikulum 2013. Oleh karena itu, RPP harus disusun guru dengan sebaik-baiknya di awal semester dan dievaluasi di akhir semester dalam rangka mencapai tujuan pendidikan.

Penyusunan RPP oleh guru memiliki beberapa tujuan. Menurut Al Tabany (2015) penyusunan RPP tidak hanya menggambarkan setting pembelajaran akan tetapi mempunyai tujuan khusus yaitu: (1) mengembangkan kreativitas dan inovasi guru dalam membuat RPP; (2) menampilkan karakteristik RPP sesuai dengan kondisi lingkungan sekolah; dan (3) mengembangkan serta meningkatkan profesionalisme guru.

Pentingnya penyusunan RPP yang dilakukan oleh guru diatur dalam Permendikbud No. 22 tahun 2016 tentang Standar Proses Pendidikan Dasar dan Menengah Bab III mengatur tentang perencanaan pembelajaran. Erviana (2016) juga menegaskan bahwa bagi guru sangat penting untuk mendesain pembelajaran di kelas yang dapat memungkinkan peserta didik lebih aktif dan kreatif guna meningkatkan kualitas peserta didik tersebut sehingga memungkinkan terjadinya proses pembelajaran di kelas dapat berjalan dengan baik.

Banyak sekali manfaat yang akan diperoleh guru setelah melakukan penyusunan RPP dengan baik. Al Tabany (2015) menjelaskan manfaat penyusunan RPP yaitu: (1) guru dapat menerapkan pembelajaran secara terprogram sehingga mempermudah, memperlancar, dan meningkatkan hasil proses pembelajaran; (2) guru dapat merancang situasi emosional yang ingin dibangun, suasana belajar yang menyenangkan, keterlibatan siswa yang aktif, sehingga terjadi suasana dialogis dan model komunikasi dua arah; dan (3) guru memiliki acuan dalam melaksanakan kegiatan pembelajaran agar lebih terarah, efektif, dan efisien. 


\section{SIMPULAN}

Berdasarkan hasil penelitian dan pembahasan yang diperoleh: (1) persentase sikap guru dalam membuat RPP kurikulum 2013 sebesar 35\% termasuk dalam kategori baik; (2) sebanyak 86\% guru mampu membuat RPP kurikulum 2013. Selain itu, indikator penilaian RPP didasarkan pada empat aspek yaitu: (1) skor rata-rata sebesar 3,16 dengan kategori baikuntuk aspek penyusunan RPP; (2) skor rata-rata sebesar 2,72 dengan kategori baik untuk aspek prinsip penyusunan RPP; (3) skor rata-rata sebesar 3,22 dengan kategori baik untuk aspek komponen dan sistematika RPP; dan (4) skor rata-rata sebesar 3,00 dengan kategori baik untuk aspek langkah-langkah penyusunan RPP. Selanjutnya dapat ditarik kesimpulan bahwa RPP kurikulum 2013 yang dibuat oleh guru Madrasah Ibtidaiyah disusun dengan baik dan dapat diimplementasikan dalam pembelajaran dengan beberapa perbaikan.

\section{DAFTAR PUSTAKA}

Al Tabany, T. I. (2015). Mendesain Pembelajaran Inovatif, Progresif, dan Kontekstual: Konsep, Landasan, dan Implementasinya pada Kurikulum 2013 (Kurikulum Tematik Integratif/KTI). Jakarta: Prenadamedia Group.

Erviana, V. Y. (2016). Pengembangan Perangkat Pembelajaran Berbasis Sosiokultural bagi Siswa Sekolah Dasar. Jurnal Prima Edukasia , 4 (2), 222232.

Hidayat, S. (2013). Pengembangan Kurikulum Baru. Bandung: Remaja Rosdakarya.

Kemdikbud. (2015). Panduan Teknis Penyusunan RPP di Sekolah Dasar. Jakarta: Kemdikbud Dirjen Pendidikan Dasar Direktorat Pembinaan Sekolah Dasar.

Machin, A. (2014). Implementasi Pendekatan Saintifik, Penanaman Karakter, dan Konservasi pada Pembelajaran Materi Pertumbuhan. Jurnal Pendidikan IPA Indonesia , 3 (1), 28 - 35.

Pitadjeng. (2009). Peningkatan Kerja Ilmiah Siswa Kelas 2 SD dengan Pengembangan Pembelajaran Tematik. Jurnal Kependidikan , 39 (2), 87 94.

Peraturan Pemerintah RI No 32 Tahun 2013. Jakarta. Presiden Republik Indonesia. 
Permendikbud No 22 Tahun 2016. Jakarta. Kementerian Pendidikan dan Kebudayaan.

Permendikbud No 67 Tahun 2013. Jakarta. Kementerian Pendidikan dan Kebudayaan.

Sugiyono. (2011). Metode Penelitian Pendidikan: Metode Penelitian Kuantitatif, Kualitatif, dan R\&D. Bandung: Alfabeta.

Undang-Undang RI No 20 Tahun 2003. Jakarta. Presiden Republik Indonesia.

Wibawa, E. A., \& Kartowagiran, B. (2014). Kesiapan Perangkat Pembelajaran Pengantar Akuntasi dalam Rangka Implementasi Kurikulum 2013. Jurnal Evaluasi Pendidikan , 2 (2) 123 - 134. 